\title{
New fossil assemblage with amber, plants and vertebrates from the lower Cenomanian near Châtellerault (Vienne, western France)
}

\author{
Xavier Valentin ${ }^{1,2, *}$, Géraldine Garcia ${ }^{1, *}$, Bernard Gomez ${ }^{3}$, Véronique Daviero Gomez ${ }^{3}$, \\ Jean-Marie Boiteau ${ }^{4}$, Simona Saint Martin ${ }^{5}$ and Jean-Paul Saint Martin ${ }^{5}$ \\ 1 PALEVOPRIM, CNRS-UMR 7262 CNRS, INEE, Université de Poitiers, 6, rue Michel Brunet, 86073 Poitiers, France \\ 2 Palaios, Association de recherche, 15, rue de l'aumônerie, 86300 Valdivienne, France \\ 3 ENSL, CNRS LGL-TPE, Université de Lyon, Univ. Lyon 1, 69622 Villeurbanne, France \\ 4 81, Avenue Jean Mermoz, 86100 Châtellerault, France \\ 5 CR2P, CNRS-UMR 7207 Centre de Recherche en Paléontologie-Paris, Muséum national d'Histoire naturelle, Sorbonne Université, \\ 8, rue Buffon, 75005 Paris, France
}

Received: 3 May 2020 / Accepted: 28 July 2020

\begin{abstract}
A large number of fossil-rich beds have been located from over $30 \mathrm{~km}$ along the Tours-Poitiers High Speed Line (LGV) during earthworks prior to its construction, and in particular amber was collected from Scorbé-Clairvaux (locality of La Bergeonneau) to the north of Poitiers. The paper describes also amber pieces from Châtellerault (locality of La Désirée) discovered during the development of sewage treatment plant along the Vienne river. Lower Cenomanian shelly sandstones and siltstones of Scorbé-Clairvaux contain rare amber pieces associated with seed plants (Frenelopsis sp., Nehvizdya sp., and angiosperm seeds) and a diversified fauna, composed of micro-remains of 27 taxa, comprising elasmobranchs (Haimirichia amonensis Cappetta and Case, 1975, Protolama sp. and Squalicorax sp.), actinopterygians (Enchodus sp. and Pycnodontidae), reptiles including vertebrae the marine snake Simoliophis rochebrunei Sauvage, 1880, some rare helochelydrid plates ( $c f$. Plastremys), teeth of three crocodilian families (Atoposauridae, Goniopholididae and Bernissartiidae) and an undetermined dinosaurian long bone fragment.
\end{abstract}

Keywords: amber / paleobotany / paleontology / lowermost Upper Cretaceous / western France

Résumé - Nouvel assemblage fossilifère avec ambre, plantes et vertébrés provenant du Cénomanien inférieur prés de Châtellerault (Vienne, ouest de la France). Un grand nombre de niveaux riches en fossiles a été trouvé sur plus de $30 \mathrm{~km}$ le long de la Ligne à Grande Vitesse (LGV) ToursPoitiers pendant les terrassements préalables à sa construction, et en particulier de l'ambre sur le site de la Bergeonneau à Scorbé-Clairvaux au nord de Poitiers. De l'ambre a également été collecté sur les bords de la Vienne au lieu-dit de La Désirée à Châtellerault lors de travaux d'aménagement d'une station d'épuration. Les grès coquillers et les roches argileuses du Cénomanien inférieur de Scorbé-Clairvaux contiennent de rares morceaux d'ambre associés à des méso-fossiles de plantes à graines (Frenelopsis sp., Nehvizdya sp. et des graines) et 27 taxons micro-fossiles de vertébrés, dont des élasmobranches (en particulier Haimirichia amonensis Cappetta et Case, 1975, Protolama sp. et Squalicorax sp), des actinoptérygiens (Enchodus sp. et Pycnodontidae), des reptiles incluant des vertèbres du serpent marin Simoliophis rochebrunei Sauvage, 1880, quelques rares plaques d'une tortue helochelydridée (cf. Plastremys), des dents de trois familles de crocodiliens (Atoposauridae, Goniopholididae et Bernissartiidae) ainsi qu'un fragment d'os long de dinosaurien indéterminé.

Mots clés : ambre / paléobotanique / paléontologie / Crétacé supérieur basal / ouest de la France

\footnotetext{
*Corresponding authors: xavier.valentin@univ-poitiers.fr; geraldine.garcia@univ-poitiers.fr
} 


\section{Introduction}

Amber-bearing deposits in the Vienne and more widely in the Poitou area have been little documented in the literature. Le Touzé de Longuemar (1866) has first reported amber pieces from the Cenomanian "green sandstones" near Chincé and Parigny, southwest of Châtellerault. Lacroix (1910) mentioned that "honey yellow resin was collected from the lignite at the base of the sandstones of Chéneché" near Marigny-Brizay. In their geological maps of Mirebeau, Cariou and Joubert (1989a, b) suggested that this amber was probably collected from lignitic claystones, fine glauconitic sands and sandstones, which are present in this area. In the 1990s, during some landscaping projects in the locality of "La Bourdillière", Saint Cyr, amateur paleontologists collected wood samples and rare altered amber pieces, today lost, from 8-m-deep lignitic claystones (M. Barkat, pers. com.). Valentin et al. (2014) has reported a few amber grains from the lower Cenomanian fossil-rich assemblage of Jaunay-Clan-Ormeau-Saint Denis; Part of the town of Jaunay-Clan is now called Jaunay-Marigny. They were collected during the LGV earthworks, and come from plant levels 10, 14 and 16 of Polette et al. (2019).

We report herein two other nearby amber localities with very similar geological settings in Châtellerault and ScorbéClairvaux. The latter locality has also yielded a diversified fauna and flora, with some taxa typically Cenomanian in age. Although the vertebrate material is fragmentary, its description provides further information concerning the poorly known fauna from the Cenomanian of France. We provide a preliminary survey of the paleobotanical and paleontological assemblages.

\section{Geological setting}

\subsection{General overview}

The Cenomanian in the westernmost margin of the Basin of Paris has been surveyed by Le Touzé de Longuemar (1866) for the geological map of the Vienne department. It consists of a continuous depositional series up to the end of Turonian, and forms an isolated hill surrounded by the valley of La Pallu to the South and by the cuesta of Envigne to the North. Paleontological excavations during the High Speed Line "LGV SEA-Sud Europe Atlantic" railroad earthwork around La Pallu conducted by the research association Palaios provided us with a thorough knowledge of the Cenomanian series, which unconformably overlies the Upper Jurassic limestones. The lowermost Cenomanian beds consist of fine gray lignitic claystones containing numerous plants megafossils and millimetric amber pieces (locality of Jaunay-ClanOrmeaux-Saint Denis, Valentin et al., 2014; Polette et al., 2019). Two new localities (Figs. 1A and 1B), ScorbéClairvaux-La Bergenonneau (SCB) and Châtellerault-La Désirée (CDR) corresponding to the base of this Cenomanian series yielded different fossil beds with diverse plant and animal assemblages (Fig. 2 and Tab. 1). The series continues up into green sandstones, already described by Mathieu (1960, 1968), and progressively reaches up into $30 \mathrm{~m}$ in thickness in Colombiers; they contain rich fossil wood and oyster shells (Exogyra colomba Lamarck, 1819), which are dated as middle Cenomanian in age (Robin et al., 2018; Boura et al., 2019). They are overlaid by upper Cenomanian marlstones, locally called "Chalk tufa", which bear Calycoceras Hyatt, 1900, by lower Turonian beds with Mammites nodosoides Schlüter, 1871 and Lewesiceras peramplum Mantell 1822, and by flint breccia deposits containing a few plant megafossil inclusions (Gomez et al., 2018).

\subsection{Scorbé-Clairvaux-La Bergeonneau (SCB)}

This fossil locality $\left(46^{\circ} 48^{\prime} 06.75^{\prime} \mathrm{N}, 0^{\circ} 23^{\prime} 18.78^{\prime} \mathrm{E}\right)$ was discovered by one of us (X.V.) in 2013 at about $1.5 \mathrm{~km}$ of the town Scorbé-Clairvaux, in a place called "La Bergeonneau" on the side of the LGV earthwork (excavation side no PK 69900). The beds mainly consist of fine, green quartz sands, sometimes brown to yellow, glauconitic with consolidated calcareous sandstones, locally called "Grison". This facies is comparable to the "sands of Vierzon" of Alcaydé et al. (1976), which correspond to the base of the Cenomanian and well exposed from Marigny Brizay to Châtellerault Boura et al. (2019). The amber grains were collected from a lenticular, dark, clayey bed at the base of the section (Fig. 2), which also plant mesofossils preserved as wood and cuticle, and in particular the conifer Frenelopsis Schenk, 1869 that this genus has been already reported from a drill core sample of Monts-sur-Guesnes (Lecointre and Carpentier, 1939). The second amber-bearing bed is richer, and it is interspersed with a blue marly limestones containing the marine mollusk genus Astartes Sowerby, 1816 and the acanthoceratid ammonite Mantelliceras lymense Spath, 1926, which is notably known from the lower Cenomanian glauconitic Chalk Formation of the Sarthe (Kennedy in Morel, 2015). The upper part of the section consists of clayey sandstones with cross-stratified sandy strips, containing numerous coarse bioclastic elements forming a lumachelle with the oysters Ceratostreon flabellatum Goldfuss, 1837 and the Rhynchostreon suborbiculatum Lamarck, 1801 associated with vertebrate remains of crocodile, marine snake, turtle and numerous selacians (Fig. 2).

\subsection{Châtellerault-La Désirée (CHD)}

During work on a sewage treatment plant in Châtellerault in 2002, one of us (J.M.B.) collected millimetric amber pieces and decimetric charred wood fragments from lignitic claystones of La Désirée locality (46 $49^{\prime} 57.38^{\prime \prime} \mathrm{N}, 0^{\circ} 322^{\prime} 31.09^{\prime}$ 'E). The stratigraphy could not be established because the fossil bed is in the river. A single unsuccessful borehole was attempted at the station's flow. The occurrence of similar gray ferruginous claystones underlying the Cenomanian green sandstones has been reported by Le Touzé de Longuemar (1866) in the locality of La Duranderie near Châtellerault (Fig. 1A).

\section{Material and methods}

\subsection{In the field}

Micro-remains were directly picked up on the prospection surfaces after the rains. Additionally, softened rocks directly collected from the bed in the field were screen-washed with water, and then cleaned with formic acid (10\%). Specimens mostly consisting of isolated teeth and bones and teeth were sorted out under a Leica stereomicroscope. 


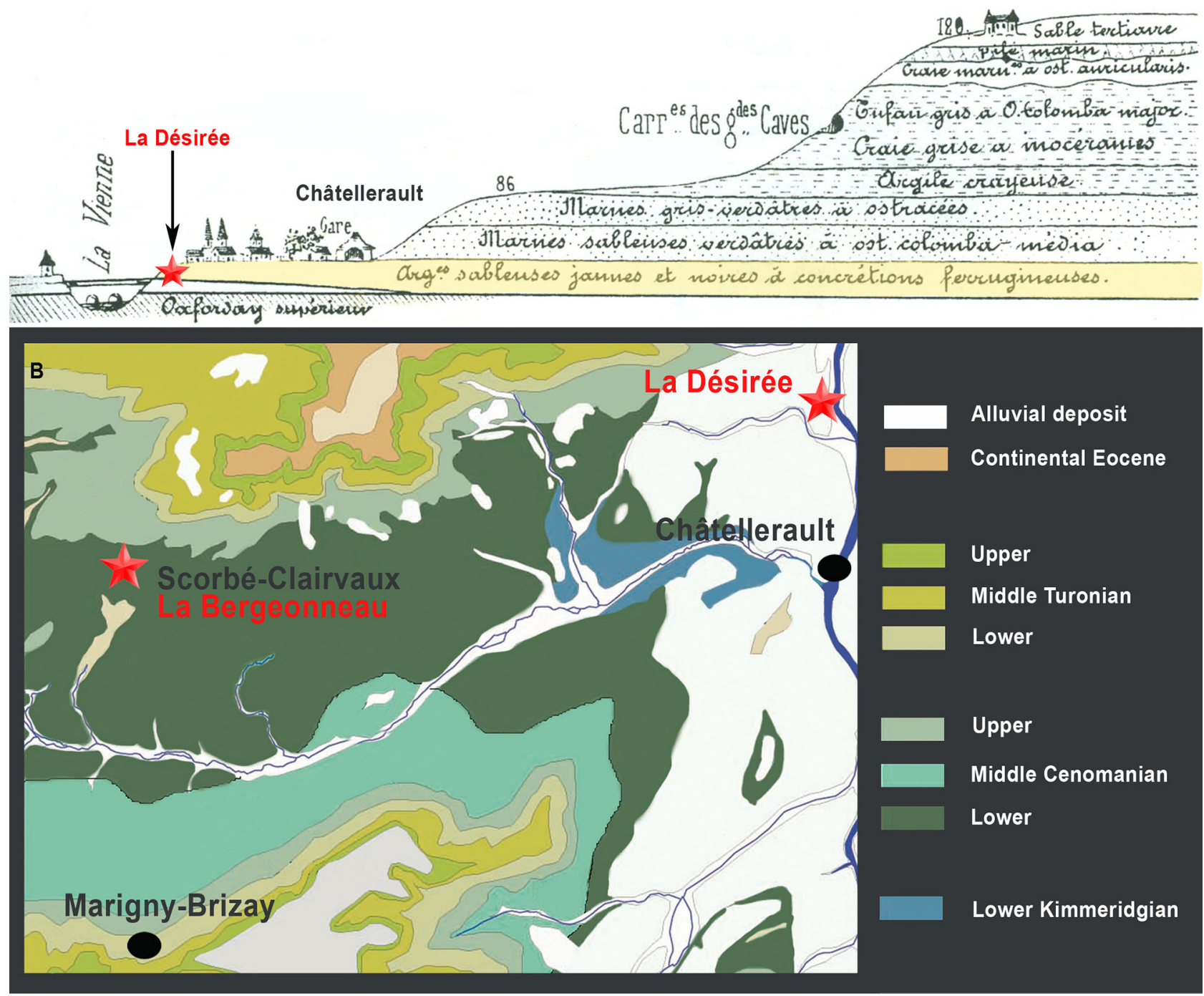

Fig. 1. Geological setting. A: Geological section of Châtellerault modified from Le Touzé de Longuemar (1866); B: Geological map showing locations of the lower Cenomanian localities: Scorbé-Clairvaux-La Bergeonneau (SCB) and Châtellerault-La Désirée (CHD), Vienne department, western France.

\subsection{Amber}

Amber samples were prepared following the procedure described by Saint Martin and Saint Martin (2018) for the study of micro-inclusions. Photographs were taken with a camera Canon PowerShot A620 mounted on a Zeiss Axioscope 40 light microscope using the Zeiss Axiovision acquisition software. Some samples either coated or uncoated were mounted on aluminum stubs. They were observed with a Hitachi SU3500 scanning electron microscope (SEM).

\subsection{Plants}

Fossil-plant-bearing claystones were soaked into a plastic box of tap water for a day, and then the resulting mud was washed through a $0.1-\mathrm{mm}-\mathrm{mesh}$ sieve. Plant fossil fragments were dried naturally, and then dry sieved with sieves of 1-mm and $0.5-\mathrm{mm}$ meshes. Specimens were sorted under a stereomicroscope Olympus SZX 10, and photographed with the same mounted with a Canon EOS 60D. Large handrock specimens were photographed with a Canon 100-mm macrolens.

All studied specimens which are catalogued UP/SCB are housed and curated by the "Centre de Valorisation des collections de l'Université de Poitiers (CVCU)".

\section{Paleontologic study}

\subsection{Amber}

\subsubsection{Scorbé-Clairvaux-La Bergeonneau (SCB)}

All amber pieces consist of fragments of originally larger blocks, and exhibit a wide range of shapes. They are translucent and red-colored (Fig. 3A). They are mostly 


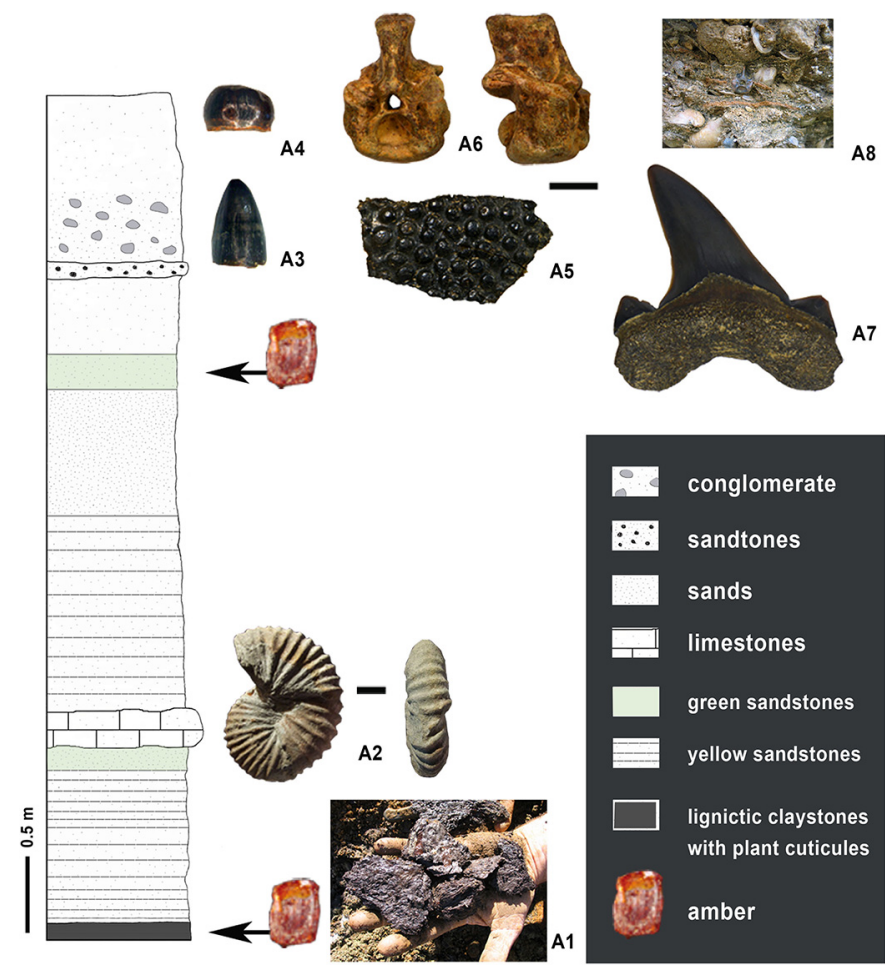

Fig. 2. Stratigraphic column of SCB with the location and the distribution of fossils; A1: Overview of level lignitic claystones with debris of plant cuticle; A2: Mantelliceras lymenense (UP/ SCB.13.008), scale bar $2 \mathrm{~cm}$; A3: Tooth of goniopholidid in labial view (UP/SCB.13.006); A4: tooth crown of a duraphagous neosuchia in labial view (UP/SCB.13.007); A5: Shell of plate $c f$. Plastremys (UP/SCB.13.003); A6: Mid trunk vertebra of Simoliophis rochebrunei in anterior and right lateral views (UP/SCB.13.005); A7: Tooth of lamniform shark Cretolamna sp. in anterior view (UP/ SCB.13.004); A8: View of the fossil bed. Scale bar for all the vertebrate specimens $5 \mathrm{~mm}$.

centimetric. They show numerous narrow fractures (Figs. 3B and $3 \mathrm{C}$ ), and are furrowed by yellow veinlets forming a sort of powdery network on the outer surface (Fig. 3A). In section they show a yellow color, and they are actually characterized by narrow fracturing lines and dense networks of filamentous appearance (Figs. 3D and 3E).

\subsubsection{Châtellerault-La Désirée (CHD)}

The amber grains really differ from those of ScorbéClairvaux in different aspects (Fig. 4A). Translucent grains usually exhibit an orange-reddish color, and a whitish crust around can be observed (Fig. 4A). Others are either rather dark brown or completely opaque. They are millimetric to centimetric. When they have the whole original size or mostly, they show the usual outer surface shrinkage cracks (Fig. 4B). Examination under the light microscope shows that the dark-brownish amber grains contain generally large bullous inclusions and/or very dense filamentous networks (Figs. 4C-4E). Some samples are characterized by very clear resin fluxes underlined by inclusions of microscopic bubbles (Figs. 4G and 4H).
Table 1. List of the vertebrate taxa from the lower Cenomanian of Scorbé-Clairvaux-La Bergeonneau (dominant taxa are indicated in bold type).

\begin{tabular}{|c|c|c|c|}
\hline Ecological preference & Marine & Brackish & Terrestrial \\
\hline \multicolumn{4}{|l|}{ Systematic } \\
\hline \multicolumn{4}{|l|}{ Elasmobranches } \\
\hline \multicolumn{4}{|l|}{ Rajiformes } \\
\hline Cantioscyllium sp. & $\mathrm{x}$ & & \\
\hline Pseudohypolophus mcnultyi & $\mathrm{x}$ & $\mathrm{x}$ & \\
\hline Ptychotrygonoides pouiti & $\mathrm{x}$ & & \\
\hline Turoniabatis cappettai & $\mathrm{x}$ & & \\
\hline \multicolumn{4}{|l|}{ Selacians } \\
\hline Archaeolamna $\mathrm{sp}$ & $\mathrm{x}$ & & \\
\hline Haimirichia amonensis & $\mathrm{x}$ & $\mathrm{x}$ & \\
\hline Cretodus semiplicatus & $\mathrm{x}$ & $\mathrm{x}$ & \\
\hline Cretolamna sp. & $\mathrm{x}$ & & \\
\hline Cederstroemia muelleri & $\mathrm{x}$ & & \\
\hline Polyacrodus maiseyi & $\mathrm{x}$ & & \\
\hline Protolamna sp & $\mathrm{x}$ & $\mathrm{x}$ & \\
\hline Protoscyliorhinus magnus & $\mathrm{x}$ & & \\
\hline Scapanorhynchus minimus & $\mathrm{x}$ & & \\
\hline Squalicorax sp. & $\mathrm{x}$ & & \\
\hline \multicolumn{4}{|l|}{ Actinopterygian } \\
\hline Ginglymodi indet & $\mathrm{x}$ & $\mathrm{x}$ & \\
\hline Pycnodontidae indet & $\mathrm{x}$ & $\mathrm{x}$ & \\
\hline Coelodus sp & $\mathrm{x}$ & $\mathrm{x}$ & \\
\hline Enchodus sp. & $\mathrm{x}$ & & \\
\hline Stephanodus & $\mathrm{x}$ & $\mathrm{x}$ & \\
\hline Ichthyodectidae indet & $\mathrm{x}$ & $\mathrm{x}$ & \\
\hline \multicolumn{4}{|l|}{ Reptilia } \\
\hline \multicolumn{4}{|l|}{ Elasmosauridae indet } \\
\hline Simoliophiidae Simoliophis rochebrunei & & $\mathrm{x}$ & \\
\hline Atoposauridae indet & & & $\mathrm{x}$ \\
\hline Goniopholididae Goniopholis sp & & & $\mathrm{x}$ \\
\hline Bernissartiidae Bernissartia $s p$ & & & $\mathrm{x}$ \\
\hline Dinosauria indet. & & & $\mathrm{x}$ \\
\hline
\end{tabular}

\subsection{Plants}

The most abundant plant fossils is by far a conifer, Frenelopsis, which is a Cretaceous representative of the extinct family Cheirolepidiaceae. There are a few large, several-timesbranched shoots (Figs. 5A and 5B), but most specimens are isolated, three-leafed, sheathing whorls (Fig. 5C). They are mostly less than $10 \mathrm{~mm}$ long and $3 \mathrm{~mm}$ wide, and even numerous narrow specimens are less than $0.5 \mathrm{~mm}$ wide. Some specimens show a single branching arising through the leafy sheath (Fig. 5D), which is typical of branching in the vegetative leafy stems (Barral et al., 2019). A few others show three branchings per whorl (Figs. 5E-5H), which are probably where male cones are borne (Daviero et al., 2001; Gomez et al., 2002). Such tiny cones are very rare, being less than $4 \mathrm{~mm}$ long and wide (Figs. 5I and 5J). They are currently in preparation in order to isolate the pollen grains that may confirm affinities with the Cheirolepidiaceae. 

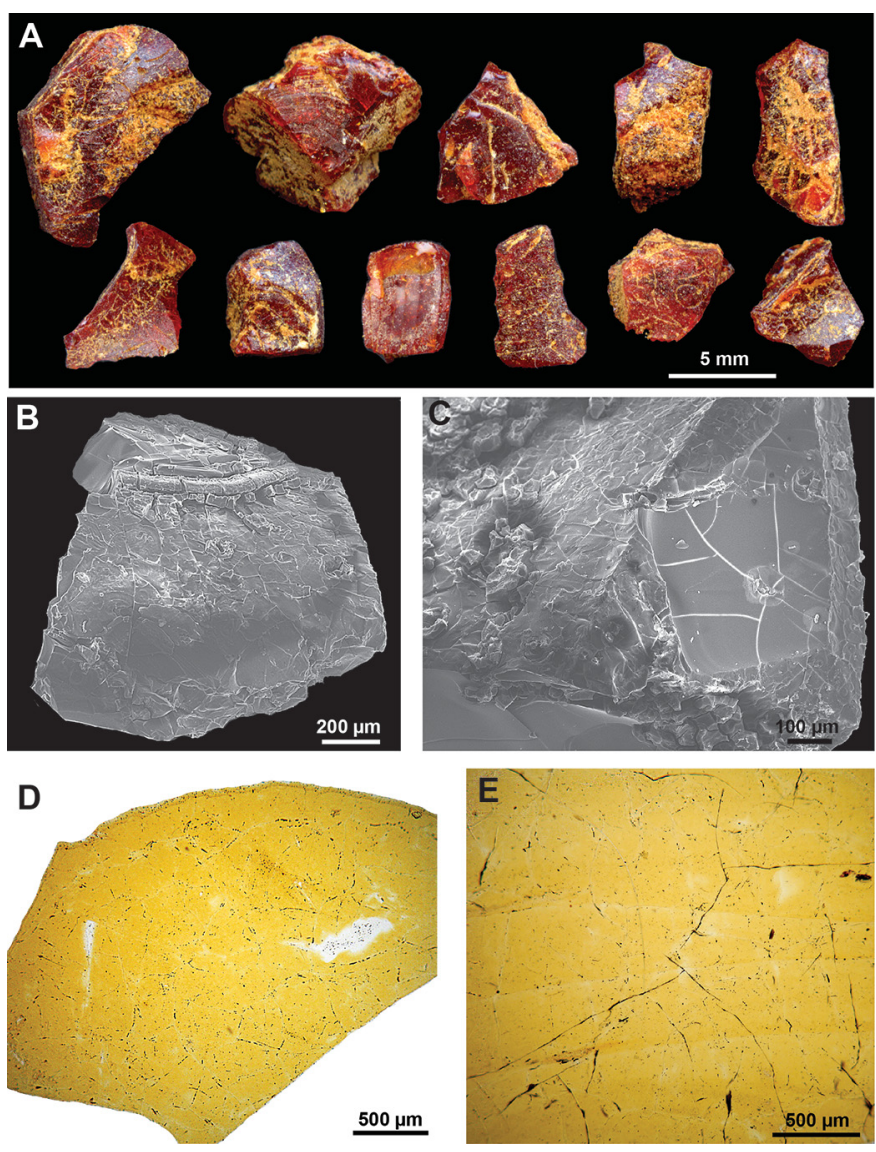

Fig. 3. Amber features of Scorbé-Clairvaux-La Bergeonneau. A: Several amber pieces showing a global reddish color with yelloworange, filamentous network; B, C: Amber samples showing finely fractured surface under the SEM; D, E: Thin sections of amber samples showing a dominant yellow color and a fine fracturing. Pictures by Jean-Paul and Simona Saint Martin.

Far less abundant are fragments of elliptic leaves of up to $15 \mathrm{~mm}$ wide showing about ten unbranched veins (Fig. 5K). These leaves are amphistomatic; on the adaxial surface stomata are randomly distributed (Fig. 5L), whereas on the abaxial surface stomatal bands alternate with non-stomatal bands along the veins (Fig. 5M Similar leaves are known as Nehvizdya Hluštík, 1977 (e.g., Gomez et al., 2000). The most abundant seeds are about $4 \mathrm{~mm}$ long and $1 \mathrm{~mm}$ wide. They show a thin tegument and an apical micropyle (Fig. $5 \mathrm{~N}$ ). The constant absence of hilum suggests that they may probably belong to Coniferophytes rather than to Angiosperms.

\subsection{Vertebrates}

The rare vertebrates from the uppermost sandstones of Scorbé-Clairvaux-La Bergeonneau consist of millimetric to centimetric teeth, vertebrae, scales and bone fragments of 27 taxa, which mainly belong to selachians. Many of the genera identified are well-known and commonly reported from the Cenomanian localities of Charentes (e.g., Vullo et al., 2005; Vullo et al., 2007; Rage et al., 2016). They represent a mixed, terrestrial and marine, ecological assemblage (Tab. 1).
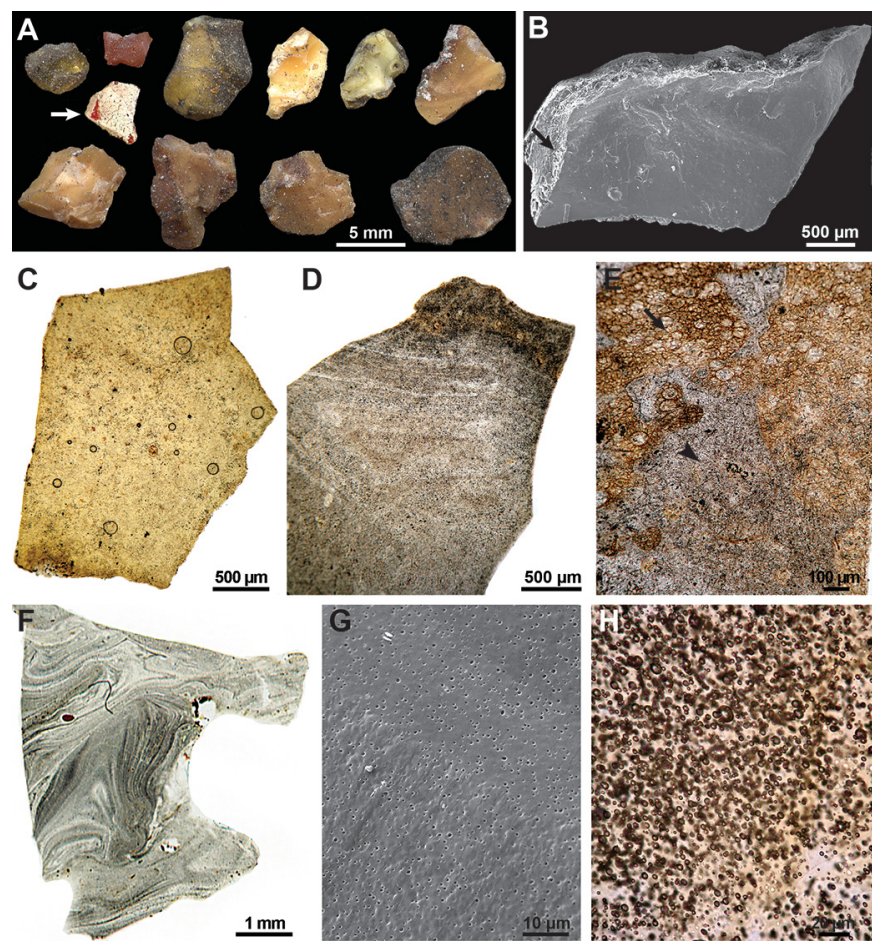

Fig. 4. Amber features of Châtellerault-La Désirée. A: Several amber pieces showing a wide range of colors and shapes, some translucent grains having a thin whitish crust (arrow); B: SEM view showing the typical fracturing on the surface of an amber grain (arrow); C, D: Thin section of opaque amber grain showing intense colonization by filamentous microorganisms; E: Thin section of opaque grain showing a mixture of bullous (arrow) and colonized (arrowhead) areas; F. Thin section of opaque amber grain showing complex resin fluxes underlined by micro-sized bubbles; G: SEM view of microbubbles; G: Thin section with detail of innumerous microbubbles. Pictures by Jean-Paul and Simona Saint Martin.

They include more than 150 elasmobranch teeth, of which two dominant Cenomanian taxa are Haimirichia amonensis Cappetta and Case, 1975 (Vullo et al., 2016) and Squalicorax sp. Among the actinopterygians, crushing teeth of pycnodontiforms and small teeth of Enchodus sp. are also relatively common. The reptiles are represented by (1) very abundant vertebrae of the ophidian Simoliophis rochebrunei Sauvage, 1880 (Fig. 2A6) characterized by their robust and pachyostotic morphology, (2) a few shell plates of helochelydrid (cf. Plastremys) with a typical bulbous granulated decoration (Fig. 2A5), (3) common teeth of three crocodilian families including the Atoposauridae, the Goniopholididae (Fig. 2A4), and the Bernissartiidae (Bernissartia Dollo, 1883; Fig. 2A3), and (4) an undetermined dinosaurian long bone fragment.

\section{Discussion}

\subsection{Paleoecological and paleoenvironmental insights}

The ambers of SCB and CHD deposited in paralic basins with inputs from both the continent and the sea based on sedimentological and paleontological settings (Guelorget and Perthuisot, 1992). These tidally-influenced, temporally and 

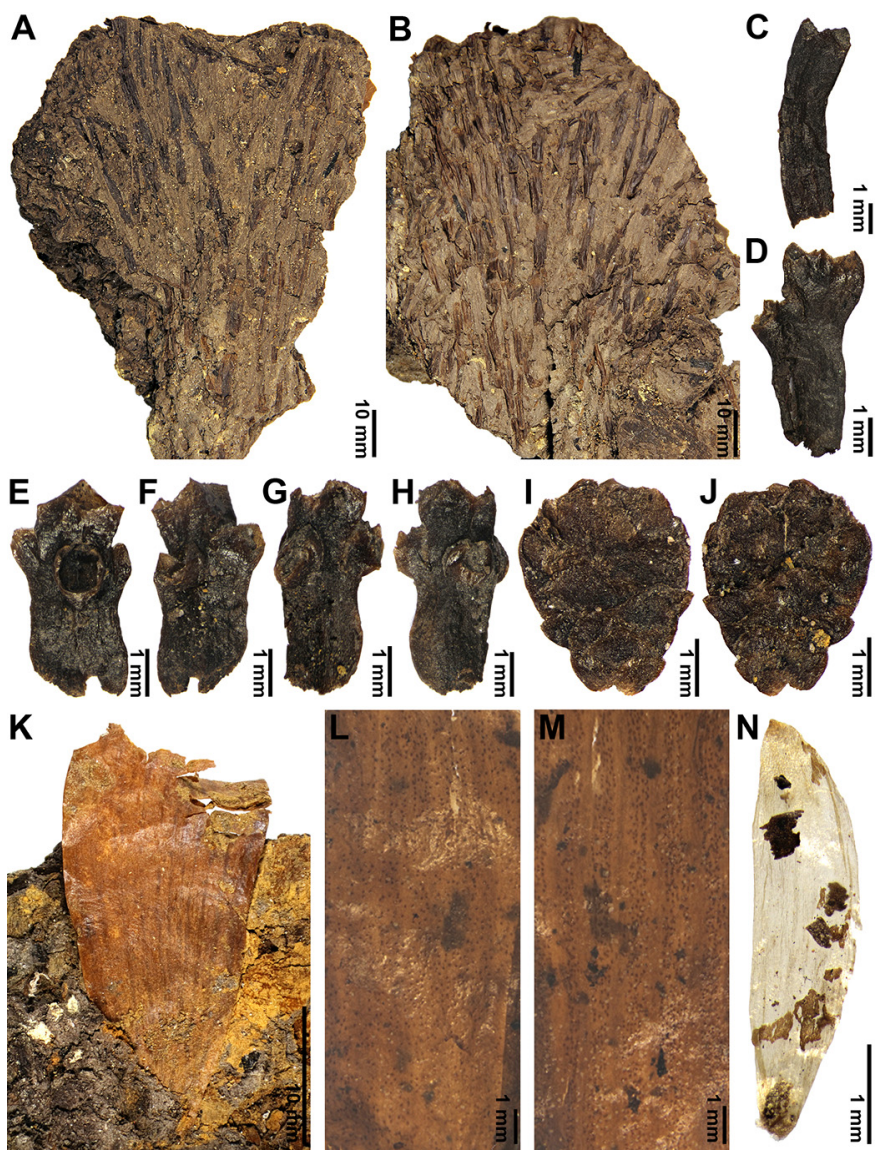

Fig. 5. Plant fossils of Scorbé-Clairvaux. A, B: Hand-rock specimens showing branched, leafy shoots of Frenelopsis sp.; C: Isolated leafy whorl of Frenelopsis showing a long leaf sheath ending by three free triangular tips; D: Isolated leafy whorl of Frenelopsis sp. showing a single lateral branching departure; E-H: Isolated leafy whorl of Frenelopsis sp. showing three lateral departures, which each probably bore a male cone; I, J: Male cone of Frenelopsis sp.; K: Hand-rock specimen showing a leaf portion of Nehvizdya sp. with unbranched veins; L: Detail of the adaxial surface of Nehvizdya sp. showing randomly distributed stomatal apparatus; M: Detail of the abaxial surface of Nehvizdya sp. showing alternation of stomatal and nonstomatal bands; N: Seed showing a micropyle (top).

spatially submerged zones corresponded to either outer estuary or lagoon marine environments. The lower Cenomanian lense of lignitic claystones in SCB that bear amber, wood and leaves of the coastal mangrove-like Frenelopsis is overlaid by a decimetric brackish bed containing the euryhaline cardiid genus Protocardia Beyrich, 1845 (Fürsich, 1994; Néraudeau et al., 2013). Then, after a short episode of marine carbonate deposition (bed with Mantelliceras lymense), yellow and green sands with fine, detrital, transported grains set up and progressively pass to coarse bioclastic sandstones with abundant marine oysters Ceratostreon flabellatum and Rhynchostreon subordiculatum, which are typical of shallow, nearshore environments (Videt and Platel, 2005). These fossil vertebrate beds are in some cases associated with fine-grained sands to lumachelles. Based on thousands of animal microfossils collected, terrestrial components are rare compared to the abundance of marine fish and margino-littoral reptiles.
These microfossils are well-preserved and mainly composed of small individuals. They were transported and deposited at short distance. Overall, and taking particularly into account taphonomic processes, such fossil deposits are often related to lagoonal environments (e.g., Vullo et al., 2003). The paralic environments are often places of intense life activity (Hogarth, 1999), which is fed by both marine and terrestrial inputs.

\subsection{Comparisons with other amber localities from the Cenomanian of western France}

The amber grains from Châtellerault are mostly small, rarely droplet-shaped, and range from translucent to opaque, which are very similar to those reported from several Cenomanian localities of western France such as in Sarthe (Breton and Tostain, 2005; Breton, 2007; Girard et al., 2013), Dordogne (Saint Martin et al., 2013a), and Mayenne (Néraudeau et al., 2020). These characteristics also prevail for ambers from different ages and origins, such as those from the Turonian of Dordogne (Néraudeau et al., 2016) and the Albian-Cenomanian and Santonian of the south-eastern France (Saint Martin et al., 2012, 2013b; Frau et al., 2020; Saint Martin et al., 2020). As in these latter ambers, the opaque appearance of certain amber grains from Châtellerault results from the colonization of the resin by networks of filamentous microorganisms like sheathed bacteria (Saint Martin and Saint Martin, 2018) and actinomyctes or a high density of bubbles. In contrast, the amber grains from Scorbé-Clairvaux show singular characteristics, especially with the veinlet network and the constant translucent appearance, which were not recognized in any other Cretaceous ambers. The microinclusion content also appears unique with only rare fungal mycelia (Saint Martin et al., work in progress).

The question of the botanical origin of amber during the Cretaceous and of its unicity per locality has been often debated. The majority of authors consider that the main producers of resin were conifers, but the main families concerned changed through the Cretaceous (for a review see Tab. 1 of Seyfullah et al., 2018). It is noteworthy that it was the time period when the Cheirolepidiaceae became extinct worldwide, the Araucariaceae decreased and are nowadays restricted into the Southern Hemisphere, whilst the Cupressaceae and to a lesser extent the Pinaceae increased. Only a few studies of Cretaceous materials indicated that there were more than one producer genus per locality during the Cretaceous. For instance Menor-Salván et al. (2010) suggested that both the Cheirolepidiaceae Frenelopsis and other undetermined botanical sources could produce resin that fossilized into a large quantity of amber from the Albian and Cenomanian of Cantabria, Spain. Moreover, Gomez et al. (2018) showed that amber solid bodies and ducts were preserved inside the mesophyll of at least five taxa (the conifers Frenelopsis and Arctopitys Bose and Manum, 1990, the two ginkgoes Nehvizdya and Pseudotorellia Florin, 1936 and one probable cycad) from the same Albian locality of El Soplao, Cantabria, Spain. So these observations suggest that resin production was, actually, a widespread response to abiotic and biotic constraints in Cretaceous gymnosperms. Frenelopsis and Nehvizdya are the two main taxa in terms of cuticle fragments in the plant fossil assemblage of Scorbé-Clairvaux, but further analysis is needed to determine whether the amber of this 
locality might originate from one, two or more botanical sources.

Acknowledgments. We are grateful to the municipalities of Châtellerault and Scorbé-Clairvaux (J.P. Abelin and L. Juge), M. Barkat, E. Blandin, P. Ferchaud and T. Valentin for field assistances, S. Riffaut and J. Thomas for technical support, and R. Vullo for help in the identification of elasmobranches and scientific discussions. This work is supported in part by the Lisea Fondation Biodiversité (research grant 97 to Palaios association with the project "Past of Biodiversity from Vienne"). We thank also S. Morel (UMR 7207 CR2P) for the preparations of thin sections and G. Toutirais (PTME, Muséum National d'Histoire Naturelle, Paris) for the observations of amber with the scanning electron microscope. We acknowledge the handling editor for inviting us to participate to this volume and the two reviewers (L. Seyfullah and the second anonymous) for their constructive comments that improved the early draft of this paper.

\section{References}

Alcaydé G, Gigout M, Cadet J-P, Lorenz J, Brosse R, Debrand Passard S, et al. 1976. Val de Loire: Anjou, Touraine, Berry (Guides géologiques régionaux). Paris : Masson, pp. 1-191.

Barral A, Gomez B, Daviero-Gomez V, Lécuyer C, Mendes MM, Ewin TAM. 2019. New insights into the morphology and taxonomy of the Cretaceous conifer Frenelopsis based on a new species from the Albian of San Just, Teruel, Spain. Cretaceous Research 95: 21-36.

Beyrich E. 1845. Protocardia, eine neue Gattung fossiler Muscheln. Zeitschrift für Malakozoologie 2: 17-20.

Breton G. 2007. La bioaccumulation de microorganismes dans l'ambre: analyse comparée d'un ambre cénomanien et d'un ambre sparnacien, et de leurs tapis algaires et bactériens. Comptes Rendus Palevol 6: 125-133.

Breton G, Tostain F. 2005. Les microorganismes de l'ambre cénomanien d'Ecommoy (Sarthe, France). Comptes Rendus Palevol 4: 31-46.

Bose MN, Manum SB. 1990. Mesozoic conifer leaves with "Sciadopitys-like" stomatal distribution. A re-evaluation based on fossils from Spitsbergen. Greenland and Baffin Island. Norsk Polarinst Skr 192: 81.

Boura A, Saulnier G, De Franceschi D, Gomez B, Daviero-Gomez V, Pons D, et al. 2019. An early record of a vesselless angiosperm from the middle Cenomanian of the Envigne valley (Vienne, Western France). Iawa Journal 40: 530-550. https://doi.org/ 10.1163/22941932-40190238.

Cappetta H, Case GR. 1975. Sélaciens nouveaux du Crétacé du Texas. Géobios 8: 303-307.

Cariou E, Joubert JM. 1989a. Carte géologique de la France (1/50000), feuille Mirebeau-en-Poitou (566). Bureau de Recherches géologiques et minières, Orléans.

Cariou E, Joubert JM. 1989b. Notice explicative, Carte géologique de la France (1/50000), feuille Mirebeau-en-Poitou (566). Bureau de recherches géologiques et minières, Orléans, $36 \mathrm{p}$.

Daviero V, Gomez B, Philippe M. 2001. Uncommon branching pattern within conifers: Frenelopsis turolensis, a Spanish Early Cretaceous Cheirolepidiaceae. Canadian Journal of Botany 79: $1400-1408$
Dollo L. 1883. Première note sur les crocodiliens de Bernissart. Bulletin du Musée Royal d'Histoire Naturelle de Belgique 2: 309-338.

Florin R. 1936. Die fossilen Ginkgophyten von Franz-Joseph-Land nebst Erörterung über vermeintliche Cordaitales mesozoischen Alters. I. Spezieller Teil. Paleontographica 81: 71-173.

Frau C, Saint Martin J-P, Saint Martin S, Mazières B. 2020. An overview of the Santonian amber-bearing deposits of the SainteBaume Massif, southeastern France. Bulletin de la Société Géologique de France.

Fürsich FT. 1994. Paleocology and evolution of the Mesozoïc salinity-controlled benthic macroinvertebrate associations. Lethaia 26: $327-346$.

Girard V, Néraudeau D, Breton G, More N. 2013. Palaeoecology of the Cenomanian amber forest of Sarthe (western France). Geologica Acta 11: 321-330.

Goldfuss GA. 1837. Petrefacta Germianiae-Abbildungen und Beschreibungen der Petrefacten Deutschlands und der angrenzenden Länder. 6. Lieferung Teil. Paleontographica 3: 141-224.

Gomez B, Martín-Closas C, Barale G, Thévenard F. 2000. A new species of Nehvizdya (Ginkgoales) from the Lower Cretaceous of the Iberian Ranges (Spain). Review of Palaeobotany and Palynology 111: 49-70.

Gomez B, Martín-Closas C, Barale G, Sole de Porta N, Thévenard F, Guignard G. 2002. Frenelopsis (Coniferales: Cheirolepidiaceae) and related male organ genera from the Lower Cretaceous of Spain. Palaeontology 45: 997-1036.

Gomez B, Daviero-Gomez V, Fradet A, Barral A. 2018. Plant cuticles from the Albian of El Soplao, Cantabria, Northern Spain. In: 10th European Palaeobotany \& Palynology Conference, University College Dublin, Ireland, 12-17 August 2018, Abstract book, 245 p.

Guelorget O, Perthuisot JP. 1992. Paralic ecosystems. Biogeological organization and functioning. Vie Milieu 42: 215-251.

Hogarth PJ. 1999. The biology of mangroves. Oxford: University Press, $228 \mathrm{p}$.

Hluštík A. 1977. The nature of Podozamites obtusus Velenovsky. Acta Musei Nationalis Pragae Series B Historia Naturalis 30: 173-186.

Hyatt A. 1900. Tetrabranchiate Cephalopoda. In: Zittel-Eastman, ed. Textbook of Palaeontology, 1st ed., pp. 502-604.

Lacroix A. 1910. Groupe des résines fossiles. Minéralogie de la France 4: 637-645.

Lamarck de J-B. 1801. Système des animaux sans vertèbres, ou table générale des classes, des ordres et des genres de ces animaux. Paris, $432 \mathrm{p}$.

Lamarck de J-B. 1819. Histoire naturelle des animaux sans vertèbres, présentant les caractères généraux et particuliers de ces animaux... 61: 1-343.

Lecointre G, Carpentier A. 1939. Sur des empreintes de Frenelopsis $\mathrm{du}$ Cénomanien provenant du forage de Monts-sur-Guesnes (Vienne). Bulletin de la Société Géologique de France 5: 583-586.

Le Touzé de Longuemar M-A. 1866. Études géologiques et agronomiques sur le département de la Vienne. Poitiers : A. Dupré, $496 \mathrm{p}$.

Mantell GA. 1822. The Fossils of the South Downs or Illustrations of the Geology of Sussex. London: Lupton Relfe, xvii +327 p.

Mathieu G. 1960. Pénétration des sédiments du Cénomanien dans le karst jurassique du Poitou. Comptes Rendus de l'Académie des Sciences de Paris 251: 755-757.

Mathieu G. 1968. Itinéraires d'excursion géologiques à SaintGeorges, Beaumont, Lencloître, Mirebeau, Tenezay, Le Terrier-duFouillou, Vasles, Poitiers. Norois 60: 522-532.

Menor-Salván C, Najarro M, Velasco F, Rosales I, Tornos F, Simoneit BRT. 2010. Terpenoids in extracts of Lower Cretaceous ambers 
from the Basque-Cantabrian Basin (El Soplao, Cantabria, Spain): Paleochemotaxonomic aspects. Organic Geochemistry 41: 1089-1103.

Morel N (coord.). 2015. Stratotype Cénomanien, Coll. Patrimoine géologique, Vol.6. Paris, Biotope, Mèze: Muséum national d'Histoire naturelle, $384 \mathrm{p}$.

Néraudeau D, Redois F, Ballèvre M, Duplessis B, Girard V, Gomez B, et al. 2013. L'ambre cénomanien d'Anjou : stratigraphie et paléontologie des carrières du Brouillard et de Hucheloup (Ecouflant, Maine-et-Loire). Annales de Paléontologie 99: 361-374.

Néraudeau D, Saint Martin S, Batten DJ, Colin J-P, Daviero-Gomez V, Girard V, et al. 2016. Palaeontology of the upper Turonian paralic deposits of the Sainte-Mondane Formation, Aquitaine Basin, France. Geologica Acta 14: 53-69.

Néraudeau D, Saint Martin J-P, Saint Martin S, Moreau J-D, Polette F, Gendry D, et al. 2020. Amber- and plant-bearing deposits from the Cenomanian of Neau (Mayenne, northern France). Bulletin de la Société Géologique de France.

Polette F, Licht A, Cincotta A, Batten DJ, Depuydt P, Neraudeau D, et al. 2019. Palynological assemblage from the lower Cenomanian plant-bearing Lagerstatte of Jaunay-Clan-Ormeau-Saint-Denis (Vienne, western France): Stratigraphic and paleoenvironmental implications. Review of Palaeobotany and Palynology. https://doi. org/10.1016/j.revpalbo.2019.104102.

Rage JC, Vullo R, Néraudeau D. 2016. The mid-Cretaceous snake Simoliophis rochebrunei, 1880 Squamata: Ophidia from its type area (Charentes, southwestern France): Rediscription, and palaeocology. Cretaceous Research 58: 234-253.

Robin N, Velasquez M, Boura A, Garcia G, Jauvion C, Boiteau JM, et al. 2018. Oldest shipworms (Bivalvia, Pholadoidea, Teredinidae) preserved with soft-parts: enlighten the morphological evolution of Pholadoidea and explain their fossil. Paleontology. https://doi.org/ 10.1111/pala.12376.

Saint Martin J-P, Saint Martin S. 2018. Exquisite preservation of a widespread filamentous microorganism from French Cretaceous ambers: a key for review of controversial fossil. Comptes Rendus Palevol 17: 415-434.

Saint Martin S, Saint Martin J-P, Girard V, Grosheny D, Néraudeau D. 2012. Filamentous micro-organisms in Upper Cretaceous amber (Martigues, France). Cretaceous Research 35: 217-229.

Saint Martin J-P, Saint Martin S, Néraudeau D. 2013a. L'ambre associé aux lignites cénomaniens du Sarladais (Dordogne, SO France). Annales de Paléontologie 99: 289-300.

Saint Martin S, Saint Martin J-P, Girard V, Néraudeau D. 2013 b. Organismes filamenteux de l'ambre du Santonien de Belcodène
(Bouches-du-Rhône, France). Annales de Paléontologie 99: 339-360.

Saint Martin J-P, Dutour Y, Ebbo L, Frau C, Mazières B, Néraudeau D, et al. 2020. Reassessment of amber bearing sites of Provence (SE France). Bulletin de la Société Géologique de France.

Sauvage H-E. 1880. Sur quelques squales de la craie des Charentes. Bulletin de la Société Géologique de France 8: 455-458.

Schenk A. 1869. Beiträge zur Flora der Vorwelt. 3. Die fossilen Plfanzen der Wernsdorfer Schichten in den Nordkarpathen. Palaeontographica 19: 1-34

Schlüter CA. 1871. Die Cephalopoden der oberen deut-schen Kreide. Palaeontographica 21: 1-24.

Seyfullah LJ, Beimforde C, Dal Corso J, Perrichot V, Rikkinen J, Schmidt AR. 2018. Production and preservation of resins - Past and present. Biological Reviews 93: 1684-1714. https://doi.org/ 10.1111/brv.12414.

Sowerby J. 1816. The Mineral conchology of Great Britain; or coloured figures and descriptions of those remains of testaceous animals or shells, which have been preserved at various times and depth in the earth. 2: 29-44.

Spath LF. 1926. Ammonites from the Black Marl of the Black Ven and Stonebarrow. Notes on some new or incompletely-known ammonites. Quarterly Journal of the geological Society of London 82: $165-179$.

Valentin X, Gomez B, Daviero-Gomez V, Charbonnier S, Ferchaud P, Kirejtshuk A, et al. 2014. Plant-dominated assemblage and invertebrates from the lower Cenomanian of Jaunay-Clan, western France. Comptes Rendus Palevol 5: 443-454.

Videt B, Platel JP. 2005. Les ostréidés des faciès lignitifères du Crétacé moyen du Sud-Ouest de la France (Charentes et Sarladais). Comptes Rendus Palevol 4: 167-176.

Vullo R, Néraudeau D, Videt B. 2003. Un faciès de type falun dans le Cénomanien basal de Charente-Maritime (France). Annales de Paléontologie 89: 171-189.

Vullo R, Néraudeau D, Allain R, Cappetta H. 2005. Un nouveau gisement à microrestes de vertébrés continentaux et littoraux dans le Cénomanien inférieur de Fouras (Charente Maritime, Sud-Ouest de la France). Comptes Rendus Palevol 4: 95-107.

Vullo R, Cappetta H, Néraudeau D. 2007. New sharks and rays from the Cenomanian and Turonian of Charentes, France. Acta Palaeontologica Polonica 52: 99-116.

Vullo R, Guimot G, Barbe G. 2016. The first articulated specimen of the Cretaceous mackerel shark Haimirichia amonensis gen. nov. (Haimirichiidae fam. nov.) reveals a novel ecomorphological adaptation within the Lamniformes (Elasmobranchii). Journal of Systematic Palaeontology 14(12): 1003-1024.

Cite this article as: Valentin X, Garcia G, Gomez B, Daviero Gomez V, Boiteau J-M, Saint Martin S, Saint Martin J-P. 2020. New fossil assemblage with amber, plants and vertebrates from the lower Cenomanian near Châtellerault (Vienne, western France), BSGF - Earth Sciences Bulletin 191: 29. 